\title{
Production of polyclonal antibodies to Batrachochytrium dendrobatidis and their use in an immunoperoxidase test for chytridiomycosis in amphibians
}

\author{
Lee Berger ${ }^{1}$, Alex D. Hyatt ${ }^{1, *}$, Veronica Olsen ${ }^{1}$, Sandra G. Hengstberger ${ }^{1}$, \\ Donna Boyle ${ }^{1}$, Gerry Marantelli ${ }^{2}$, Kaye Humphreys ${ }^{3}$, Joyce E. Longcore ${ }^{4}$ \\ ${ }^{1}$ Australian Animal Health Laboratory, CSIRO Livestock Industries, Private Bag 24, Geelong, Victoria 3220, Australia \\ ${ }^{2}$ Amphibian Research Centre, PO Box 424, Brunswick, Victoria 3056, Australia \\ ${ }^{3}$ Veterinary and Quarantine Centre, Taronga Zoo, PO Box 20, Mosman, New South Wales 2088, Australia \\ ${ }^{4}$ Department of Biological Sciences, University of Maine, Orono, Maine 04469-5722, USA
}

\begin{abstract}
Polyclonal antibodies were produced for diagnosing chytridiomycosis in amphibians. Two sheep and 4 rabbits were inoculated with homogenized whole culture of Batrachochytrium dendrobatidis in Freund's complete adjuvant or triple adjuvant. Antisera from all animals reacted strongly with all stages of $B$. dendrobatidis and stained the walls, cytoplasm, rhizoids and zoospores in an indirect immunoperoxidase test. Significant cross-reactivity occurred only with some fungi in the Chytridiomycota, and there are no members of this phylum besides $B$. dendrobatidis that infect frogs. The immunoperoxidase stain is a useful screening test when combined with recognition of the morphology and infection site of $B$. dendrobatidis.
\end{abstract}

KEY WORDS: Batrachochytrium dendrobatidis · Chytridiomycosis $\cdot$ Fungus $\cdot$ Amphibians $\cdot$ Immunoperoxidase $\cdot$ Polyclonal antibodies $\cdot$ Diagnosis

\section{INTRODUCTION}

Chytridiomycosis is a fatal disease of amphibians caused by the fungus Batrachochytrium dendrobatidis, the only member of the Chytridiomycota that causes disease in vertebrates (Berger et al. 1999). This fungus has a broad amphibian host range and occurs worldwide. A total of 94 amphibian species from 15 families have been found infected with $B$. dendrobatidis, from Australia, South America, Central America, North America, Europe, New Zealand and Africa (Speare et al. 2001). Chytridiomycosis is the most common disease of Australian frogs (Berger et al. 1999). Although amphibian population declines are often due to habi-

*E-mail: alex.hyatt@csiro.au tat modification and multi-factorial causes (Alford \& Richards 1999), the suspected introduction of chytridiomycosis to wild amphibians is the most likely cause of many declines in protected areas (Berger et al. 1999).

Chytridiomycosis is a highly infectious disease that appears to have spread nationally and internationally, possibly by movement of infected animals. Diagnosis of infected amphibians will be an important aspect of quarantine regulations aimed at preventing the introduction of disease to wild or captive populations. Current diagnostic tests rely on knowledge of the morphology of the fungus for identification by histology or examination of wet mounts of skin scrapings. Most sick frogs with chytridiomycosis have heavy infections with Batrachochytrium dendrobatidis that are easily recognized by standard histopathological techniques (Pessier et al. 1999, Berger et al. 2000). However histological 
diagnosis is insensitive when dealing with light infections in healthy animals or autolysed samples, or when tests are performed by inexperienced workers.

Diagnostic methods with improved sensitivity and ease of testing are needed. The production of polyclonal antibodies and the introduction of an immunoperoxidase (IPX) stain are the first steps in the development of more sophisticated tests for the detection of antigen.

\section{MATERIALS AND METHODS}

Antigen for immunization. A culture of Batrachochytrium dendrobatidis (isolate A98 1810/3) was obtained from a sick, wild adult Australian lacelid (Nyctimystes dayi). The culture was maintained on tryptone, gelatin hydrolysate agar (Longcore et al. 1999) for 5 mo before use. Sporangia were harvested by lightly scraping a $10 \mathrm{~d}$ old culture. Thirty milligrams of culture was mixed with $1 \mathrm{ml}$ distilled water and left for $24 \mathrm{~h}$ at room temperature, then manually homogenized in a sterile petri dish and frozen at $-80^{\circ} \mathrm{C}$. After defrosting, the mixture was diluted with phosphate buffered saline (calciumand magnesium-free) (PBSA) to a final concentration of $3.25 \mathrm{mg} \mathrm{ml}^{-1}$. The protein concentration was determined using a Pyr Unicam PU8800 UV/VIS spectrophotometer at $280 \mathrm{~nm}$, by interpolation of its absorbance from a standard curve calculated from known concentrations of bovine serum albumin $(0.25,0.5$, 1.0 and $5.0 \mathrm{mg} \mathrm{ml}^{-1}$ ). Freund's complete adjuvant and triple adjuvant (Quil A, DEAE-dextran, Montanide 888 oil) (Prowse 2000) were prepared using a Sorvall Omnimixer for emulsification. The final protein concentration of antigen in both preparations was $0.5 \mathrm{mg} \mathrm{ml}^{-1}$ antigen.

Immunization. Two rabbits (666 and 667) and 1 sheep (322) were inoculated with triple adjuvant intradermally with boosters at 7 and $11 \mathrm{wk}$ post inoculation (pi). Two rabbits (668 and 669) and 1 sheep (386) were inoculated with Freund's complete adjuvant subcutaneously and boosted with Freund's incomplete adjuvant at 7 and $11 \mathrm{wk}$ pi. At each inoculation, the rabbits received $0.5 \mathrm{mg}$ fungus in $1 \mathrm{ml}$ adjuvant and the sheep received $1 \mathrm{mg}$ fungus in $2 \mathrm{ml}$ adjuvant.

At $13 \mathrm{wk}$ pi, serum from all animals were strongly stained for Batrachochytrium dendrobatidis in the IPX test (refer below), and at $15 \mathrm{wk}$ pi animals were bled out under anesthesia (Australian Animal Health Laboratory, animal ethics approval no. 97-797). Blood was collected into SST gel and clot activator vacutainers. It was stored at $4{ }^{\circ} \mathrm{C}$ for up to $2 \mathrm{~d}$ before centrifuging at 3000 rpm (Beckman J-6 M centrifuge) for $3 \mathrm{~min}$. Serum was stored in $10 \mathrm{ml}$ sterile Starstedt tubes at $-80^{\circ} \mathrm{C}$.

Fungal isolates for cross reactivity testing. Specimens of Batrachochytrium dendrobatidis from Aus- tralia, Ecuador, New Zealand and Germany were tested with the antisera. Ten other chytridiomycetes and 18 fungi from other phyla causing animal infections (including fungi from frogs, reptiles and fish) were obtained from various collections (Table 1). Most fungi were in agar cultures, but some identifiable fungi within animal tissues were also used. Two protozoans in amphibian tissue were also tested: a myxozoan and a coccidian. Samples of agar or tissue were fixed in $10 \%$ neutral buffered formalin, processed into paraffin blocks and sectioned for IPX staining.

IPX test. For indirect IPX staining, paraffin sections were dewaxed and incubated for 20 min with $0.1 \%$ trypsin in $0.1 \%$ aqueous $\mathrm{CaCl}_{2}$ at $37^{\circ} \mathrm{C}$ for antigen unmasking. Slides were rinsed in distilled water and PBSA, loaded into Sequenza cassettes (Shandon, UK) and incubated with $200 \mu \mathrm{l}$ of the anti-chytrid antisera at various dilutions in $0.1 \%$ skim milk powder/PBSA for $1 \mathrm{~h}$ at $37^{\circ} \mathrm{C}$. After a 5 min rinse with PBSA, slides were incubated with biotinylated anti-rabbit, anti-goat immunoglobulin (Dako large volume DAKO LSAB kit, DAKO Corp, Carpinteria, CA, USA) for $20 \mathrm{~min}$ at $37^{\circ} \mathrm{C}$. Slides were rinsed with PBSA then incubated with $3 \%$ $\mathrm{H}_{2} \mathrm{O}_{2}$ in distilled water for $20 \mathrm{~min}$ at room temperature $\left(22^{\circ} \mathrm{C}\right)$ to block endogenous peroxidase activity. After rinsing in PBSA, slides were incubated with streptavidin peroxidase conjugated (DAKO LSAB kit) for $20 \mathrm{~min}$ at $37^{\circ} \mathrm{C}$, rinsed again, then removed from the Sequenza cassettes. The antigenic complex was visualized using a 3-amino-9-ethyl carbasole (AEC) chromogen system (Sigma). The substrate and chromogen (freshly made AEC solution [2 mg AEC powder in $200 \mu \mathrm{l}$ dimethyl formamide] added to $10 \mathrm{ml} 0.05 \mathrm{M}$ acetate buffer with $5 \mu l 30 \%$ hydrogen peroxide) were added and incubated at room temperature for $5 \mathrm{~min}$. After washing, slides were counterstained in Lillie's modified hemalum, blued in Scott's tap water, rinsed in tap water and mounted in an aqueous mounting medium.

Negative controls consisted of test slides incubated with normal sera, pre-bleed sera or $1 \%$ skim milk instead of primary antibody. Sections of Batrachochytrium dendrobatidis culture (A98 1810/3) and sections of infected skin from a green tree frog (Litoria caerulea) (A99 1385/1) were used as positive control slides.

The IPX test was used to indicate the titer of antibodies from each animal (rabbits and sheep) and to characterize the cross-reactivity of antibodies with other fungi. These fungi are listed in Table 1.

Evaluation of the IPX test for diagnosis. Preliminary evaluation of the IPX as a diagnostic assay was conducted on 55 lightly infected and 15 control toe-clip samples from an experimental infection using juveniles of Litoria caerulea. The toe-clips were collected 
Table 1. List of fungal species used, their strain identification numbers, the order and phylum they belong to, and their source. A: from Lee Berger, Australian Animal Health Laboratory, Australia; E: from Andrés Merino-Viteri, Museo de Zoologia, Quito, Ecuador; G: from Frank Mutschmann, Tierarztpraxis, Berlin, Germany; JEL: from the chytrid collection of Joyce Longcore, University of Maine, Maine, USA; N: from Bruce Waldman and Richard Norman, Massey University, New Zealand; T: from Kaye Humphreys and Karrie Rose, Taronga Zoo, Australia

\begin{tabular}{|c|c|c|c|c|}
\hline Species & $\begin{array}{l}\text { Strain } \\
\text { identification }\end{array}$ & Order & Phylum & Source \\
\hline Batrachochytrium dendrobatidis & A $981810 / 3$ & Chytridiales & Chytridiomycota & $\begin{array}{l}\text { Australian lacelid } \\
\text { (Nyctimystes dayi) }\end{array}$ \\
\hline Chytriomyces angularis & JEL 45 & Chytridiales & Chytridiomycota & Pollen bait \\
\hline Diplochytridium lagenarium & JEL 72 & Chytridiales & Chytridiomycota & Oedogonium sp. (algae) \\
\hline Karlingiomyces sp. & JEL 93 & Chytridiales & Chytridiomycota & Snakeskin bait \\
\hline Powellomyces sp. & JEL 95 & Spizellomycetales & Chytridiomycota & Pollen bait \\
\hline Rhizophydium sp. & JEL 136 & Chytridiales & Chytridiomycota & Pollen bait \\
\hline Multiple axes & JEL 142 & Chytridiales & Chytridiomycota & Onion skin bait \\
\hline Rhizophydium sp. & JEL 151 & Chytridiales & Chytridiomycota & Lyngbya sp. (algae) \\
\hline Gonapodya sp. & JEL 183 & Monoblepharidales & Chytridiomycota & Lemna sp. \\
\hline Asterophlyctis sarcoptoides & JEL 186 & Chytridiales & Chytridiomycota & Shrimp chitin bait \\
\hline Allomyces macrogynus & JEL 204 & Blastocladiales & Chytridiomycota & Snakeskin bait \\
\hline Fusarium culmorum & Т 801/99 & Hypocreales & Ascomycota & $\begin{array}{l}\text { Blotched blue-tongued } \\
\text { lizard (Tiliqua nigrolutea) }\end{array}$ \\
\hline Phaeoacremonium parasiticum & Т 819/99 & Moniliales & Ascomycota & $\begin{array}{l}\text { Bearded dragon } \\
\text { (Pogona barbata) }\end{array}$ \\
\hline Fusarium oxysporum (1) & $\mathrm{T}$ & Hypocreales & Ascomycota & $\begin{array}{l}\text { Blotched blue-tongued } \\
\text { lizard (Tiliqua nigrolutea) }\end{array}$ \\
\hline Fusarium oxysporum (2) & Т 801/99 & Hypocreales & Ascomycota & $\begin{array}{l}\text { Blotched blue-tongued } \\
\text { lizard (Tiliqua nigrolutea) }\end{array}$ \\
\hline Trichophyton terrestre & T 1067/00 & Onygenales & Ascomycota & $\begin{array}{l}\text { Blue-tongued lizard } \\
\text { (Tiliqua scincoides) }\end{array}$ \\
\hline Paecilomyces lilacinus & $\mathrm{T} 1618 / 1$ & Eurotiales & Ascomycota & $\begin{array}{l}\text { Yellow anaconda } \\
\text { (Eunectes notaeus) }\end{array}$ \\
\hline Penicillium sp. & Т 1440.1 & Eurotiales & Ascomycota & $\begin{array}{l}\text { Green and gold bell frog } \\
\text { (Litoria aurea) }\end{array}$ \\
\hline Candida sake & Т 1103.1 & Saccharomycetales & Ascomycota & $\begin{array}{l}\text { Green and gold bell frog } \\
\text { (Litoria aurea) }\end{array}$ \\
\hline Fusarium sp. & Т 1670.1 & Hypocreales & Ascomycota & $\begin{array}{l}\text { Gouldian finch } \\
\text { (Erythrura gouldiae) }\end{array}$ \\
\hline Gliocladium sp. & Т 1212 & Hypocreales & Ascomycota & $\begin{array}{l}\text { Murray cod } \\
\text { (Maccullochella peelii) }\end{array}$ \\
\hline Verticillium sp & Т 1212 & Moniliales & Ascomycota & $\begin{array}{l}\text { Murray cod } \\
\text { (Maccullochella peelii) }\end{array}$ \\
\hline Chrysosporium sp. & Т 1333 & Onygenales & Ascomycota & $\begin{array}{l}\text { Hosmer's skink } \\
\text { (Egernia hosmeri) }\end{array}$ \\
\hline Acremonium sp. & Т 1697.1 & Hypocreales & Ascomycota & $\begin{array}{l}\text { Diamond python } \\
\text { (Morelia spilota) }\end{array}$ \\
\hline Scopulariopsis brevicaulis & Т 1258 & Microascales & Ascomycota & $\begin{array}{l}\text { Black-headed python } \\
\text { (Aspidites melanocephalus) }\end{array}$ \\
\hline Trichoderma viride & Т 1344 & Hypocreales & Ascomycota & $\begin{array}{l}\text { Freshwater crocodile } \\
\text { (Crocodylus johnstoni) }\end{array}$ \\
\hline Monochaetia sp. & Т 1226 & Melancoliales & Ascomycota & $\begin{array}{l}\text { Little penguin } \\
\text { (Eudyptula minor) }\end{array}$ \\
\hline Mucor amphibiorum (tissue) & A $961429 / 3$ & Mucorales & Zygomycota & Cane toad (Bufo marinus) \\
\hline Aphanomyces sp. (tissue) & A 95517 & Saprolegniales & Oomycota & Cane toad (Bufo marinus) \\
\hline B. dendrobatidis (tissue) & N 30916-00B & Chytridiales & Chytridiomycota & $\begin{array}{l}\text { Southern bell frog } \\
\text { (Litoria raniformis) }\end{array}$ \\
\hline B. dendrobatidis (tissue) & E QCAZ 3691 & Chytridiales & Chytridiomycota & Atelopus sp. \\
\hline B. dendrobatidis (tissue) & G 99 1743/3 & Chytridiales & Chytridiomycota & $\begin{array}{l}\text { Yellow-lined poison dart } \\
\text { frog (Phyllobates lugubris) }\end{array}$ \\
\hline Myxidium immersum (tissue) & A $96570 / 1$ & Bivalvulida & Myxozoa & $\begin{array}{l}\text { Stony creek frog } \\
\text { (Litoria lesueuri) }\end{array}$ \\
\hline Goussia-like coccidian (tissue) & A 01 95/4 & Eimeriidae & Apicomplexa & $\begin{array}{l}\text { Great barred frog } \\
\text { (Mixophyes fasciolatus) }\end{array}$ \\
\hline
\end{tabular}


$19 \mathrm{~d}$ after frogs were exposed to 50000 zoospores. All infected frogs eventually died from chytridiomycosis between 24 and $67 \mathrm{~d}$ after exposure. Sections of toe-clips were stained using antiserum from rabbit 667 diluted 1:1000. The results from the IPX test were compared with results from hematoxylin and eosin (H\&E) staining. Sections of a naturally infected wild tadpole of Mixophyes fasciolatus were tested with antisera from all animals.

Fluorescence staining. For direct fluorescence staining, cultured Batrachochytrium dendrobatidis grown on glass slides were incubated with rabbit 667 antiserum diluted 1:100 in $0.1 \%$ bovine serum albumin/PBSA for $30 \mathrm{~min}$ at $37^{\circ} \mathrm{C}$. After washing in PBSA, slides were incubated with 1:100 diluted anti rabbit immunoglobulin G conjugated with fluorescein isothiocyanate (Silenus, Boronia, Australia) for $30 \mathrm{~min}$ at $37^{\circ} \mathrm{C}$. They were then washed and mounted in glycerol. Slides were examined with a Reichert-Jung (Leica) Polyvar microscope with a tungsten lamp and a filter for fluorescence.

Electron microscopy. Both cultures of Batrachochytrium dendrobatidis were pelleted in $1.5 \%$ low gelling temperature agarose (Type VII) (Sigma) in $0.1 \mathrm{M}$ caco-

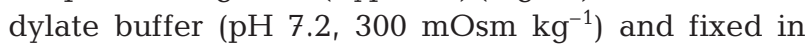
$0.25 \%(\mathrm{v} / \mathrm{v})$ buffered glutaraldehyde for $40 \mathrm{~min}$. The samples were then processed as described by Hyatt (1991) and embedded in LR White. Ultra-thin sections were cut with a Reichart-Jung (Leica) Ultracut $E$ and immuno-gold labeled (Hyatt 1991) with rabbit (666) anti $B$. dendrobatidis (1:1000). Sections were then double- stained with uranyl acetate and lead citrate before examination with a Philips CM 120 transmission electron microscope at $100 \mathrm{kV}$.

\section{RESULTS}

Antisera from all animals reacted strongly with isolates of Batrachochytrium dendrobatidis when used at dilutions between 1:100 and 1:1600 in the indirect IPX test on sections of culture and of infected skin. All stages of $B$. dendrobatidis were stained, and the walls, cytoplasm, septa, rhizoids and internal zoospores were highlighted

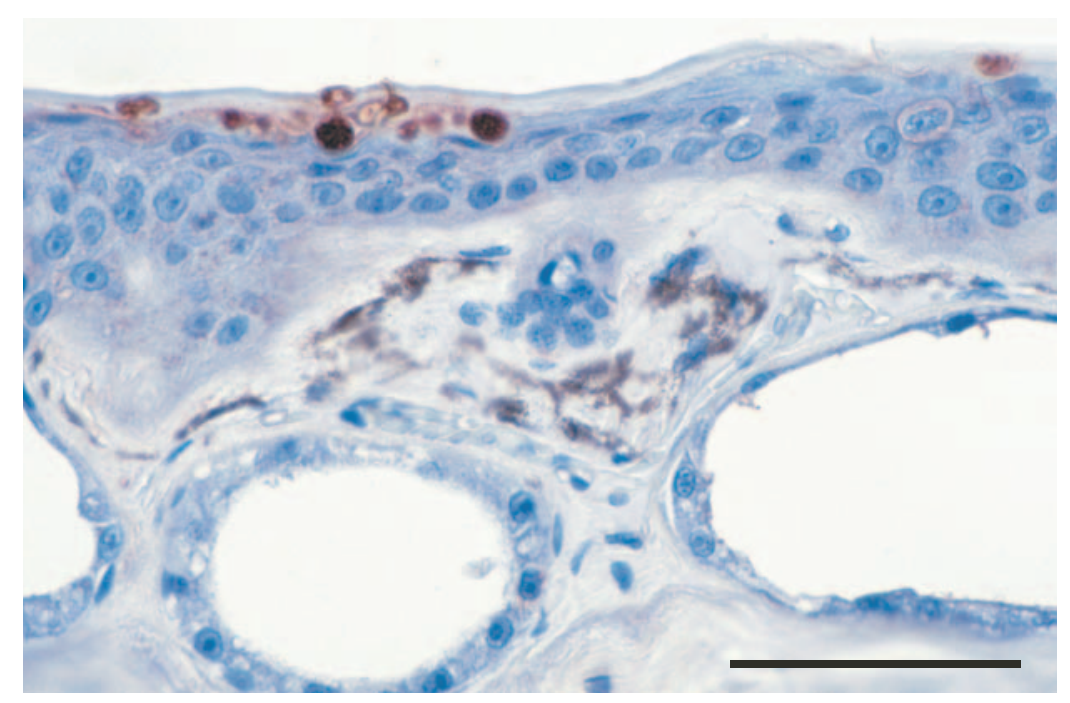

Fig. 2. Immunoperoxidase stain on skin of a Litoria caerulea with a light infection of Batrachachytrium dendrobatidis, showing the sensitivity of the test in highlighting a few sporangia. Scale bar $=80 \mu \mathrm{m}$ 


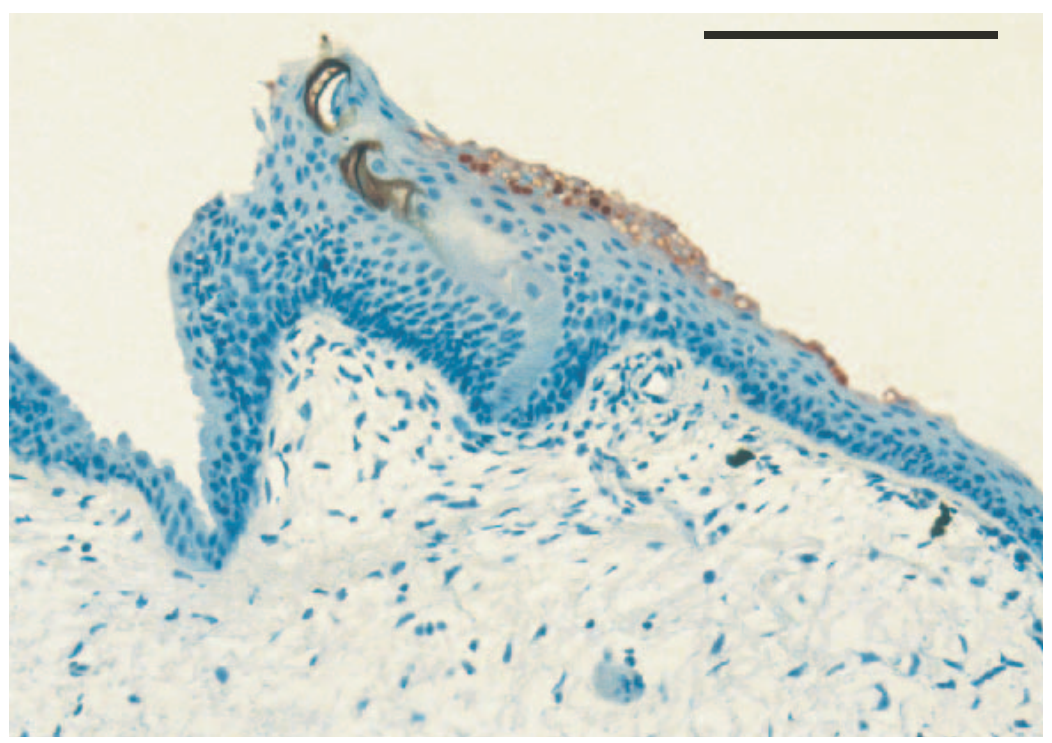

Fig. 3. Immunoperoxidase stain on the mouth parts of a tadpole of Mixophyes fasciolatus infected with Batrachachytrium dendrobatidis. Scale bar $=200 \mu \mathrm{m}$

between 6 out of 10 and 9 out of 10 other chytridiomycetes. Most of this cross-reactivity disappeared when the antisera were used at 1:1000, although a Karlingiomyces sp. (no. 93) and an undescribed isolate known as 'multiple axes' (no. 142) were still stained by rabbit antisera. Less cross-reactivity occurred with fungi from other phyla; antisera from rabbits and sheep reacted with between 3 out of 18 and 8 out of 18 fungi when used at 1:100, but staining was negligible at 1:1000. The 2 protozoans were not stained. Fungi that cross-reacted at 1:1000 were also incubated with antisera diluted out to $1: 2000$, but they were still stained (data not shown).

Evaluation of the stain on toe-clips from experimentally infected frogs showed that the IPX test was more sensitive than H\&E staining for diag-

cultured Batrachochytrium dendrobatidis when used at dilutions of 1:100 but not of 1:500. Sera collected from sheep before vaccination showed some staining at 1:100 and 1:500 but not at 1:1000. It was not determined whether this staining was non-specific or due to pre-existing antibodies in the animals.

There was cross-reactivity between antisera and a large number of fungi (Table 3). Significant staining is represented by $>2+$ in the table. The strongest staining occurred with fungi in the Chytridiomycota, but reactions also occurred with fungi in other phyla. Staining of other fungal species was sometimes limited to 1 or 2 distinct structures, e.g. zoospores, rhizoids, cytoplasm or cell walls, showing that these fungi had different antigens in common with Batrachochytrium dendrobatidis. When used at 1:100, antisera cross-reacted with

Table 2. Intensity of staining in the immunoperoxidase test using various concentrations of antisera against Batrachochytrium dendrobatidis. Animals 666, 667 and 322 were inoculated with triple adjuvant, and animals 668, 669 and 386 were inoculated with Freund's adjuvant. At higher dilutions, cell walls faded before zoospores

\begin{tabular}{|lccccccc|}
\hline Dilution & $\begin{array}{c}\text { Rabbit } \\
666\end{array}$ & $\begin{array}{c}\text { Rabbit } \\
667\end{array}$ & $\begin{array}{c}\text { Rabbit } \\
668\end{array}$ & $\begin{array}{c}\text { Rabbit } \\
669\end{array}$ & $\begin{array}{c}\text { Sheep } \\
322\end{array}$ & $\begin{array}{c}\text { Sheep } \\
386\end{array}$ \\
\hline $1: 400$ & +++++ & +++++ & +++++ & +++++ & +++++ & +++++ \\
$1: 800$ & +++++ & +++++ & +++++ & ++++ & +++++ & ++++ \\
$1: 1600$ & ++++ & ++++ & ++++ & +++ & +++++ & ++++ \\
$1: 3200$ & +++ & +++ & ++++ & ++ & ++++ & ++ \\
$1: 6400$ & +++ & +++ & +++ & ++ & +++ & + \\
$1: 12800$ & + & ++ & ++ & - & ++ & - \\
$1: 25600$ & + & + & + & - & + & - \\
\hline
\end{tabular}

nosis of chytridiomycosis. With the IPX test, 34 of 55 $(62 \%)$ frogs tested positive, compared with 29 of 55 (53\%) positives and 3 suspicious positives with H\&E staining. Fifteen controls were negative by both methods. On re-examination of 4 negative or suspicious H\&E sections that were positive by immunostaining, a few sporangia were recognized in the sections - these were mostly solid, immature stages within viable epidermal cells and were difficult to differentiate from cell nuclei. The stain was also effective in highlighting infection in the mouth of a tadpole (Fig. 3).

Fluorescence staining of cultured fungi resulted in strong staining of the surface of sporangia, and rhizoids were clearly outlined. Transmission electron microscopy of ultra-thin sections showed sporangia and zoospores to be gold labeled (Fig. 4). Labeling was strongly associated with the inner aspect of the sporangial wall, the limiting membrane of the zoospores, flagella and the contents of the zoospore vacuoles.

\section{DISCUSSION}

The antisera that were produced in this study will be valuable in improving diagnostic screening assays for the detection of Batrachochytrium dendrobatidis in amphibians. Although there was some cross-reactivity with other fungi, the antisera did not cross-react with other fungi known to infect amphibians. When the rabbit antisera were diluted out to 1:1000, apart from 2 chytridiomycetes, only $B$. dendrobatidis remained strongly stained. As structures of other fungi were still stained at the higher dilution the antibodies cannot be 


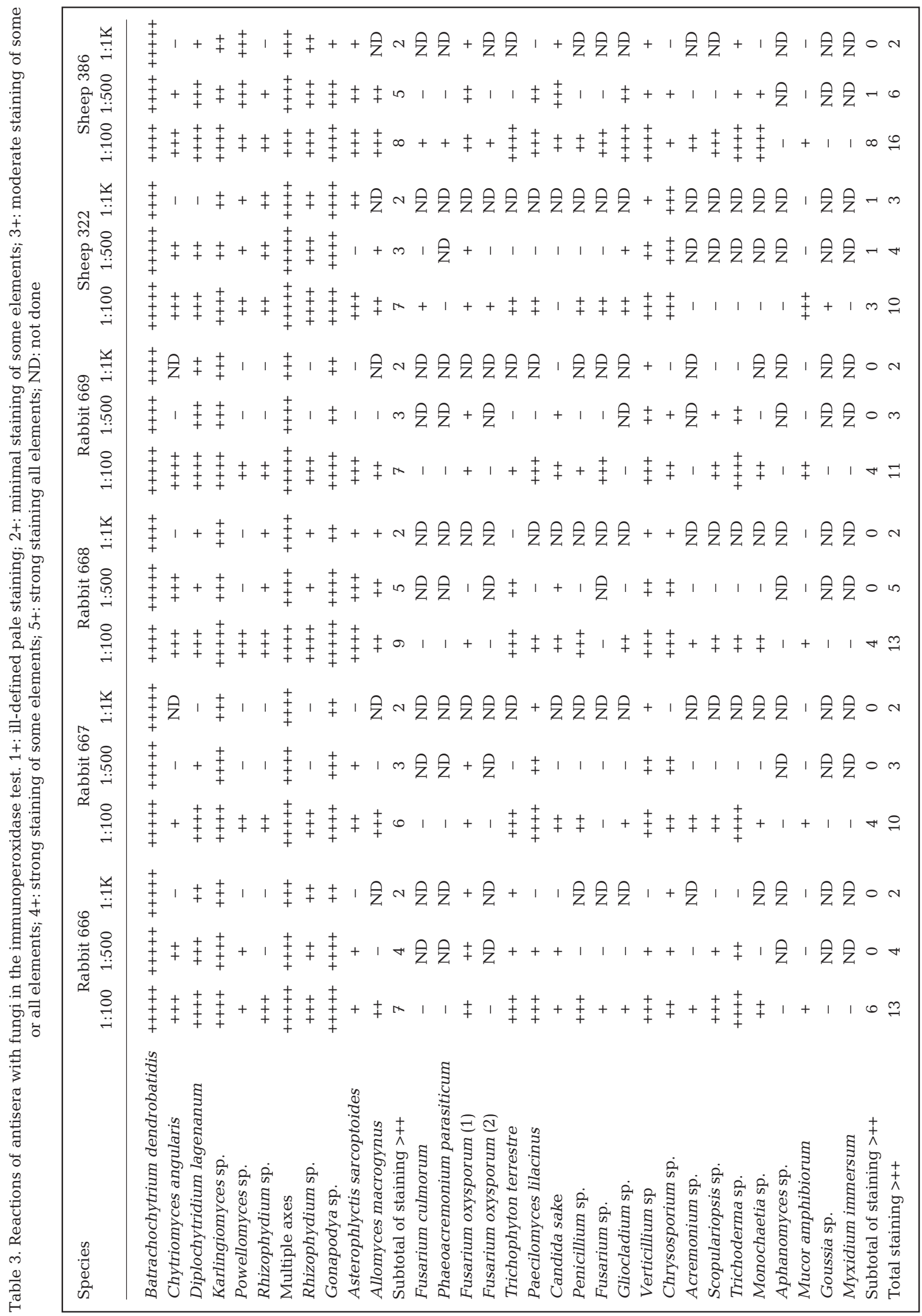




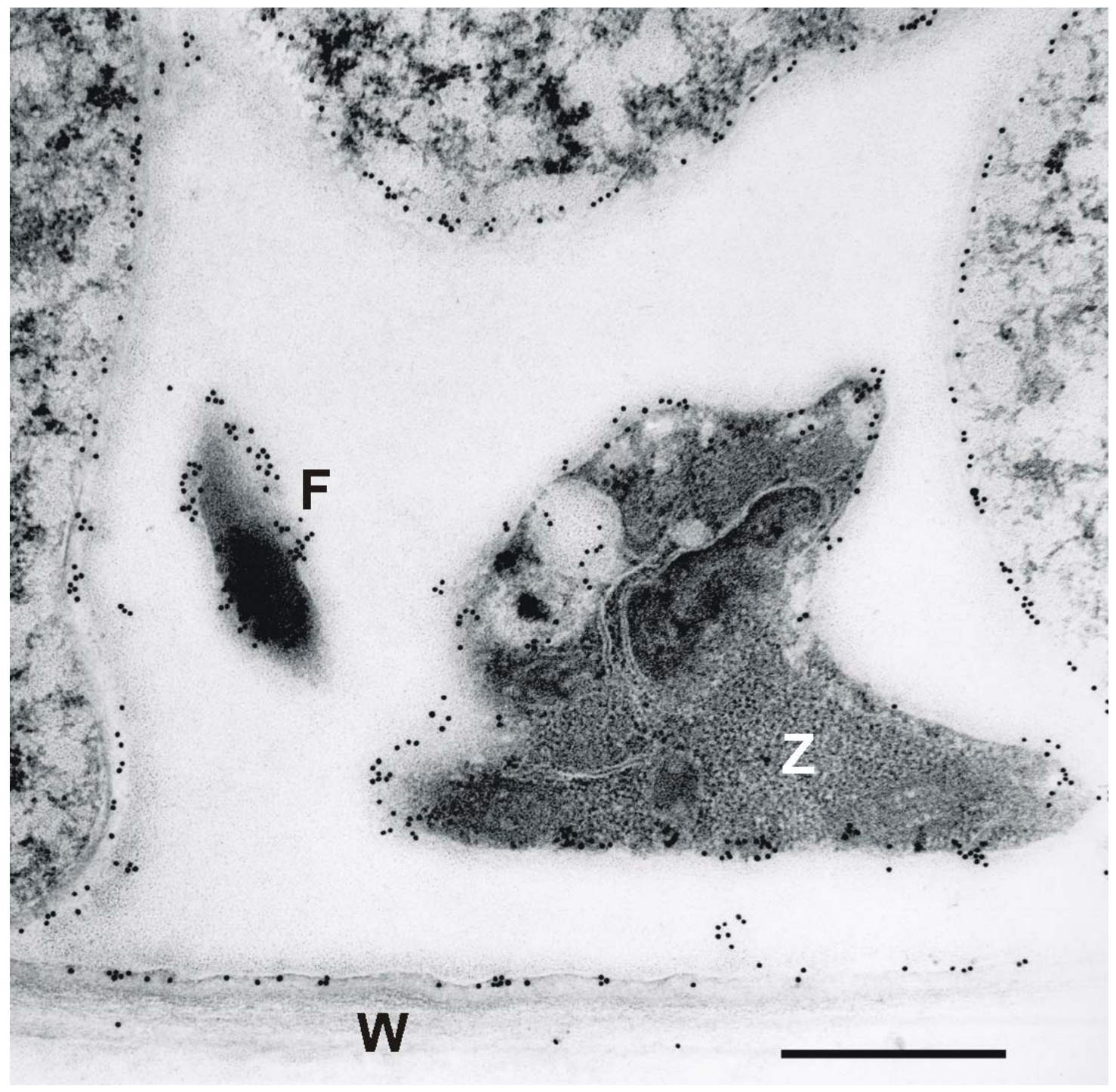

Fig. 4. Electron micrograph of a gold-labeled cultured zoosporangium, using polyclonal antiserum from rabbit 666. Note dense gold particles adhering to the inner edge of the wall (W), the membrane of the zoospore (Z), and the surface of the flagellum (F). Scale bar $=500 \mathrm{~nm}$

considered to be species specific. The only other spherical fungus reported to infect amphibian skin in Australia is Mucor amphibiorum (Speare et al. 1997) and this fungus was not stained. The 2 fungi that crossreacted strongly are chytridiomycetes, none of which are known to infect amphibians. One of these was the undescribed chytrid labeled 'multiple axes' (JEL 42), which groups most closely with $B$. dendrobatidis in some 18S rDNA phylogenetic analyses (James et al. 2000). The other strongly stained species, Karlingiomyces sp. (JEL 93), is phylogenetically distant in analyses of $18 \mathrm{~S}$ rDNA sequence data.

Polyclonal antibodies are usually cross-reactive between fungal species, and even monoclonal antibodies are often not specific (Fenelon et al. 1999). Carbohydrates and glycoconjugates on cell walls may be highly antigenic and have epitopes common to a range of species (Gabor et al. 1993). Electron microscopy of goldlabeled sections showed that our polyclonal antibodies were directed mainly to the sporangial wall and zoospore membrane. Preparations containing only internal structures have been found to generate monoclonal antibodies that are more species specific (Gabor et al. 1993).

The polyclonal antibodies we produced are a basis for further work and the IPX test may be useful for detecting or confirming infection with Batrachochytrium dendrobatidis in frog skin. Histological meth- 
ods may be less sensitive than other methods (e.g. enzyme-linked immunosorbent assays) as only small skin samples, such as toe-clips, can be collected ante mortem. Furthermore, sections contain just a thin strip of skin and may miss any sporangia. The IPX test can be used instead of, or as an adjunct to, H\&E staining when increased sensitivity of testing is required, such as for importation of amphibians. It is useful for screening toe-clip samples from healthy frogs where only a few sporangia may be present, and these can be easily seen even at low magnification. The stain is also useful for testing necrotic or autolyzed samples from sick frogs that may contain few distinctive sporangia. In addition, the ease of interpretation of the assay permits scientists other than specialists (e.g. pathologists and mycologists) to diagnose infection. The benefits of increased sensitivity and quicker examination of slides stained by the IPX test must be weighed against the greater complexity of the staining method, which takes about $4 \mathrm{~h}$.

It is recommended that the rabbit antisera be diluted to $1: 1000$ for immunostaining and that interpretation of results include examination of stained structures for the characteristic appearance of Batrachochytrium dendrobatidis (Berger et al. 1998, Pessier et al. 1999).

The data reported in this paper are part of a research effort into improving the diagnostic capability for the detection of chytridiomycosis (Hyatt et al. 2000). The immunostaining protocol is the first reported assay for the detection of Batrachochytrium dendrobatidis antigens. The polyclonal antibodies are being used in the development of an indirect enzyme-linked immunosorbent assay. Monoclonal antibodies to B. dendrobatidis are being evaluated for use in more specific tests. We do not know which type of antibody or test will prove to be the most useful for detection of $B$. dendrobatidis in amphibians, but the IPX test described here using polyclonal antibodies can now be used for improved diagnosis.

Acknowledgements. We are very grateful to Khin Than for help with preparing the adjuvants. Thanks to Susanne Wilson and Sandy Matheson for inoculation and care of rabbits and sheep, Raelene Hobbs for assistance with the frog experiment, Megan Braun and Gail Russell for helping develop the immunoperoxidase test, Karrie Rose for supplying fungal specimens, and Rick Speare and Ken McColl for comments on the manuscript. This work was supported by funding from the National Science Foundation, USA, and Environment Australia.

Editorial responsibility: Peernel Zwart, Utrecht, The Netherlands

\section{LITERATURE CITED}

Alford RA, Richards SJ (1999) Global amphibian declines: a problem in applied ecology. Annu Rev Ecol Syst 30: 133-165

Berger L, Speare R, Daszak P, Green DE and 10 others (1998) Chytridiomycosis causes amphibian mortality associated with population declines in the rainforests of Australia and Central America. Proc Natl Acad Sci USA 95:9031-9036

Berger L, Speare R, Hyatt A (1999) Chytrid fungi and amphibian declines: overview, implications and future directions. In: Campbell A (ed) Declines and disappearances of Australian frogs. Environment Australia, Canberra, p 23-33

Berger L, Speare R, Kent A (2000) Diagnosis of chytridiomycosis in amphibians by histologic examination. Zoos' Print J 15:184-190

Fenelon LE, Hamilton AJ, Figueroa JI, Bartholomew MA, Allen MH, McCarthy P, Hay RJ (1999) Production of specific monoclonal antibodies to Aspergillus species and their use in immunohistochemical identification of Aspergillosis. J Clin Microbiol 37:1221-1223

Gabor BK, O'Gara ET, Philip BA, Horan, DP, Hardham AR (1993) Specificities of monoclonal antibodies to Phytophthora cinnamomi in two rapid diagnostic assays. Plant Dis 77:1189-1197

Hyatt AD (1991) Immunogold labelling techniques. In: Harris R (ed) Electron microscopy in biology: a practical approach. Oxford University Press, Oxford, p 59-80

Hyatt AD, Berger L, Olsen V, Boyle D, Hengstberger S (2000) Advances in the development of diagnostic assays for the detection of the amphibian chytrid fungus (genus Batrachochytrium). In: Moore K, Speare R (eds) Getting the jump on amphibian disease. Conference and Workshop Compendium, 26 to 30 August 2000, Cairns, Queensland. Rainforest CRC, Cairns, p 25

James TY, Porter D, Leander CA, Vilaglys R, Longcore JE (2000) Molecular phylogenetics of the Chytridiomycota supports the utility of ultrastructural data in chytrid systematics. Can J Bot 78:336-350

Longcore JE, Pessier AP, Nichols DK (1999) Batrachochytrium dendrobatidis gen. et sp. nov., a chytrid pathogenic to amphibians. Mycologia 91:219-227

Pessier AP, Nichols DK, Longcore JE, Fuller MS (1999) Cutaneous chytridiomycosis in poison dart frogs (Dendrobates spp.) and White's tree frogs (Litoria caerulea). J Vet Diagn Invest 11:194-199

Prowse S (2000) A new adjuvant. ANZCCART News 13(3):7

Speare R, Berger L, O'Shea P, Ladds PW, Thomas AD (1997) Pathology of mucormycosis of cane toads in Australia. J Wildl Dis 33:105-111

Speare R, Core Working Group of Getting the Jump on Amphibian Disease (2001) Nomination for listing of amphibian chytridiomycosis as a key threatening process under the Environment Protection and Biodiversity Conservation Act 1999. In: Speare R, Steering Committee of Getting the Jump on Amphibian Disease. Developing management strategies to control amphibian diseases: decreasing the risks due to communicable diseases. School of Public Health and Tropical Medicine, James Cook University, Townsville, p 163-187

Submitted: July 15, 2001; Accepted: August 16, 2001

Proofs received from author(s): March 13, 2002 